\title{
Reading alchemically: guides to 'philosophical' practice in early modern England
}

\author{
Jennifer M. Rampling* \\ Department of History, Princeton University, Princeton, NJ 08544, USA \\ *Corresponding author: Jennifer M. Rampling, email:rampling@princeton.edu
}

\begin{abstract}
Dozens of early modern treatises claim to offer straightforward instructions on the theory and practice of alchemy, including all the steps necessary to produce the philosophers' stone and a range of medicinal elixirs. Yet the resulting works often seem to obfuscate more than they explain: omitting vital information, disguising ingredients and practices behind cover names, and describing outcomes that seem, to modern eyes, impossible. Were such 'instruction manuals' ever intended to offer guides for actual practice, or did they serve other ends - from attracting patrons to persuading sceptics of the truth of alchemy? Drawing upon alchemical dialogues written, compiled and annotated by English alchemists in the late fifteenth and the sixteenth centuries, I argue that these works of 'philosophical' alchemy could indeed serve as technical manuals, although not always of the kind we might expect. Such writings offer advice not only on practical techniques, but also on the process of reading alchemically: guiding readers through the exegetical minefield of alchemical writing, in order both to extract meaningful chemical recipes from obscure texts, and to craft the practitioner's own persona as an alchemical philosopher.
\end{abstract}

Alle the gramarians of Inglond \& of fraunce, Can not teche yow those concordance. ${ }^{1}$

The art of alchemy has no shortage of 'how-to' literature. In early modern Europe, men and women with alchemical interests used texts as a major source of information on practice. These include large numbers of recipes gathered together without overarching commentary, in Kunstbücher, books of secrets and monastic recipe collections. ${ }^{2}$ They also comprise hundreds of treatises that are presented not as practicae (although they often include recipes) but as works of 'alchemical philosophy' that delve into the conceptual

1 Thomas Norton, Ordinal of Alchemy (ed. John Reidy), London, New York and Toronto: Oxford University Press for the Early English Text Society, 1975, p. 52 (11. 1643-4).

2 See, inter alia, William Eamon, Science and the Secrets of Nature: Books of Secrets in Medieval and Early Modern Culture, Princeton, NJ: Princeton University Press, 1994; Sylvie Neven, 'Transmission of alchemical and artistic knowledge in German mediaeval and premodern recipe books', in Sven Dupré (ed.), Laboratories of Art: Alchemy and Art Technology from Antiquity to the 18th Century, Springer: Cham, 2014, pp. 23-51; Peter M. Jones, 'The survival of the frater medicus? English friars and alchemy in medieval England, ca. 1370-ca. 1425', Ambix (2018) 65, pp. 23249. On English recipe culture more generally see Elaine Leong, Recipes and Everyday Knowledge: Medicine, Science, and the Household in Early Modern England, Chicago: The University of Chicago Press, 2019.

(C) The Author(s), 2020. Published by Cambridge University Press on behalf of British Society for the History of Science. This is an Open Access article, distributed under the terms of the Creative Commons Attribution-NonCommercial-NoDerivatives licence (http://creativecommons.org/licenses/by-nc-nd/4.0/), which permits non-commercial re-use, distribution, and reproduction in any medium, provided the original work is unaltered and is properly cited. The written permission of Cambridge University Press must be obtained for commercial re-use or in order to create a derivative work. 
underpinnings of material change. Such treatises are typically based on the authority of past adepts (usually referred to as 'philosophers'), and discuss the practice of alchemy in relation to its theory. ${ }^{3}$ They often obtained wide circulation in manuscript, and later in print. They were studied by readers whose annotations reveal intense engagement with their practical content. On the face of it, they look like manuals.

But what exactly were these books of alchemical know-how intended to achieve - or, to put it another way, what were they manuals of? Often, the stated aim of alchemical treatises is to teach the principles of correct practice, including tips on avoiding the errors commonly made by 'fools', or false practitioners. Their writers insist that the philosophers' instructions, if correctly understood, will enable readers to confect a host of spectacular arcana: actual material products that range from the philosophers' stone (a transmuting agent capable of turning base metals into gold and silver) to medicinal elixirs for prolonging life and curing intractable diseases. At the same time, these guides obscure as much as they reveal. Methods for making alchemical elixirs are typically disguised through the use of metaphors, symbols, cover names and strategic lacunae, decipherable only with time, effort, wisdom and (as writers frequently warn) the grace of God. At first glance, such techniques seem peculiarly ill-suited to the task of training others in chemical operations. Yet alchemical authors tend to present the obscurity of their writing not as a bug, but as a feature: a strategy intended to weed out unworthy practitioners, since only true philosophers will have the wit to understand them.

The premise that practical content can be learned from texts, but only from those that are encoded to the point of illegibility, gives alchemy a special place in the history of books and reading. ${ }^{4}$ Across disciplines, early modern readers employed a variety of techniques both to parse the meaning of texts, and to apply their contents to real-world situations and events. ${ }^{5}$ While deliberate encipherment greatly increased the difficulty of understanding and applying textual content, in the case of alchemical texts these difficulties also encouraged specific readerly responses, including multi-layered, allegorical interpretations of seemingly intractable passages. By implication, practical success in alchemy depended on the acquisition of a sophisticated set of reading techniques: a process that went beyond simply learning a new technical vocabulary to encompass scholarly methods of textual exegesis. ${ }^{6}$ Writers and compilers of alchemical treatises regularly insist that

3 I discuss the notion of alchemical philosophy, and practitioners' self-identification as 'philosophers', in Jennifer M. Rampling, The Experimental Fire: Inventing English Alchemy, 1300-1700, Chicago: The University of Chicago Press, forthcoming 2020. On the structure of medieval alchemical treatises, which often comprise both a 'theorica' and a 'practica', see also Robert Halleux, Les textes alchimiques, Turnhout: Brepols, 1979, pp. $79-81$.

4 The place of alchemy within histories of reading is briefly discussed in Richard Calis, Frederic Clark, Christian Flow, Anthony Grafton, Madeline McMahon and Jennifer M. Rampling, 'Passing the book: cultures of reading in the Winthrop family, 1580-1730', Past and Present (2018) 241, pp. 69-141. On the scholarly techniques used to construe alchemical texts see also William R. Newman and Lawrence M. Principe, Alchemy Tried in the Fire: Starkey, Boyle, and the Fate of Helmontian Chymistry, Chicago: The University of Chicago Press, 2002; Bruce T. Moran, Andreas Libavius and the Transformation of Alchemy: Separating Chemical Cultures with Polemical Fire, Sagamore Beach, MA: Science History Publications, 2007; Jennifer M. Rampling, 'Transmuting sericon: alchemy as "practical exegesis" in early modern England', Osiris (2014) 29, pp. 19-34.

5 On these techniques in the context of English humanism see particularly Lisa Jardine and Anthony Grafton, “"Studied for action": how Gabriel Harvey read his Livy', Past and Present (1990) 129, pp. 30-78; William H. Sherman, John Dee: The Politics of Reading and Writing in the English Renaissance, Amherst: University of Massachusetts Press, 1995.

6 The interpretive challenges posed by such texts have long been recognized. For some recent attempts to decipher encoded practical operations see Lawrence Principe, "Chemical translation” and the role of impurities in alchemy: examples from Basil Valentine's Triump-Wagen', Ambix (1987) 34, pp. 21-30; William R. Newman, Gehennical Fire: The Lives of George Starkey, an American Alchemist in the Scientific Revolution, Cambridge, MA: 
practitioners must learn to approach texts in a philosophical way, warning of the exegetical perils ahead, but also promising to enlighten readers' ignorance by expounding difficult terms and unpacking allegories. Such writings therefore differ from recipes that record procedures in the form of sequential instructions involving identifiable ingredients, often honed through testing and tweaking. ${ }^{7}$ Philosophical writings, in contrast, offer support to novices by teaching them how to read 'alchemically'.

In this article, I approach alchemical treatises not just as technical handbooks, but as manuals of reading practice. Although works of alchemical philosophy could take many forms, from extended prose treatises to pseudepigraphic epistles and dream poems, I concentrate here on a specific genre - the dialogue - as it developed in fifteenth- and sixteenth-century England. As a didactic genre commonly used in both learned and artisanal contexts, dialogue was well suited to alchemical applications. Some of the most influential works of early alchemy were structured as dialogues between a master and a student - or even, in the case of the medieval Turba philosophorum, as a conversation between an entire conference of distinguished ancient authorities. ${ }^{8}$

In England, medieval dialogues served as models for a variety of new alchemical treatises, ranging from anonymous, vernacular adaptations of Latin exemplars to the learned, Latin productions of Henry VIII's librarian, Giles Du Wes (d. 1535). Such models helped to compensate for the lack of dedicated institutional settings for alchemical study. Alchemy was not formally taught in the curriculum of a European university until 1609, and then only in the context of chemical medicine and pharmacy. ${ }^{9}$ Nor were there guilds to regulate practice. The treatises produced by individual practitioners therefore offer valuable insights into how natural-philosophical knowledge was learned and communicated outside these institutions, and the ways in which reader-practitioners used didactic texts to shape their own personae as philosophers. For instance, claims about the exclusivity and philosophical status of alchemy helped to generate prestige for writers and their work: a form of intellectual currency particularly prized by those who lacked a traditional Scholastic education (like Giles Du Wes) or elite connections (like the Elizabethan haberdasher Richard Walton).

Fictive dialogues also helped to shape real conversations. Through the transcription, exchange and shared reading of alchemical manuscripts, reader-practitioners absorbed philosophical tropes that came to inform their interactions with one another - exchanges recorded in their correspondence and textual annotations. By the mid-sixteenth century, English practitioners from a variety of backgrounds, mercantile and artisanal as well as clerical, were confidently promoting philosophical claims in their own writings, whether composed in English or in Latin. ${ }^{10}$ For these budding adepts, the intricacies of alchemical

Harvard University Press, 1994, Chapter 4; Lawrence M. Principe, The Secrets of Alchemy, Chicago: The University of Chicago Press, 2013, Chapter 6; Principe, 'Chymical exotica in the seventeenth century, or, how to make the Bologna stone', Ambix (2016) 63, pp. 118-44; William R. Newman, Newton the Alchemist: Science, Enigma, and the Quest for Nature's 'Secret Fire', Princeton, NJ: Princeton University Press, 2018.

7 See particularly Leong, op. cit. (2).

8 Julius Ruska (ed.), Turba Philosophorum: Ein Beitrag zur Geschichte der Alchemie, Berlin: Springer, 1931; Didier Kahn, 'The Turba philosophorum and its French version (15th c.)', in Miguel López Pérez, Didier Kahn and Mar Rey Bueno (eds.), Chymia: Science and Nature in Medieval and Early Modern Europe, Newcastle upon Tyne: Cambridge Scholars, 2010, pp. 70-114. On the 'conference of philosophers' trope see Jennifer M. Rampling, 'Transmission and transmutation: George Ripley and the place of English alchemy in early modern Europe', Early Science and Medicine (2012) 17, pp. 477-99.

9 Bruce T. Moran, Chemical Pharmacy Enters the University: Johannes Hartmann and the Didactic Care of Chymiatria, Madison: American Institute of the History of Pharmacy, 1991. Alchemy was a 'novitas' in Latin Europe in the twelfth century, following the translation of Arabic texts into Latin; accordingly, its adherents had to make the case for its authority. Halleux, op. cit. (3), pp. 70-2.

10 Rampling, op. cit. (3), Chapters 2-3. 
reading opened the door not just to practical secrets, but also to personal authority within communities of like-minded readers. ${ }^{11}$ As we shall see, such lessons might carry weight even in the absence of operative success.

\section{Teaching alchemically}

In medieval 'how-to' literature, one of the most frequently encountered methods for expounding knowledge is through dialogue. Whether literary, philosophical or technical, dialogues provided a modus docendi for all kinds of subject matter, from Latin grammar to the pursuit of love. ${ }^{12}$ The format virtually reconstructs pedagogical relationships, dramatizing lists of 'frequently asked questions' in which a master delivers suitable precepts and responds to his pupils' concerns. The role of master could also be assumed by historical and allegorical figures: most famously by the personification of Philosophy in Boethius's Consolation of Philosophy, in whose presence the philosopher assumes the role of acolyte. ${ }^{13}$

Such literary imaginings of the master-disciple relationship were particularly apt for alchemy, as a body of knowledge that was both philosophical and technical in content, but which lacked formal mechanisms of instruction. Dialogues re-created the conditions under which secret knowledge might be privately communicated, whether by an anonymous magister, a named authority or an allegorical personification such as Nature or Philosophy. Examples already proliferate in the early Greek alchemical corpus, from the dialogue of Synesius and Dioscorus (in which the philosopher Synesius expounds a still earlier authority, Pseudo-Democritus), to a set of dialogues involving the female alchemist Cleopatra, who takes on the role either of student or of master, depending on her audience. ${ }^{14}$

In text after text, eager students press their 'master' for advice on solving alchemical problems. Yet these problems are typically less concerned with communicating technical skills than they are with construing texts. In one of the earliest such examples, a disciple of Synesius seeks advice on interpreting the writings of Pseudo-Democritus:

Dioscorus. How can I become intelligent, my philosopher? I want to learn the method from you; for if I try to follow what has been said, I will not have any benefit from that.

- Listen to him speaking, O Dioscorus, and sharpen your mind, Dioscorus. Look at how he says: 'Turn their nature inside out ... for nature is hidden inside'.

- O Synesius, what extraction is he speaking about?

- He speaks about the extraction of one of the (metallic) bodies.

- And how can I turn it [i.e. the nature] inside out? How can I lead the nature outside?

- Sharpen your mind, O Dioscorus, and turn your attention to how he speaks ... ${ }^{15}$

11 On community reading practices more generally, particularly in the seventeenth century, see Elizabeth Yale, Sociable Knowledge: Natural History and the Nation in Early Modern Britain, Philadelphia: University of Pennsylvania Press, 2016.

12 On the evolution of the dialogue form in late antiquity and the Latin Middle Ages see, respectively, Simon Goldhill (ed.), The End of Dialogue in Antiquity, Cambridge: Cambridge University Press, 2008; Carmen Cardelle de Hartmann, Lateinische Dialoge, 1200-1400: Literaturhistorische Studie und Repertorium, Leiden: E.J. Brill, 2006.

13 Seth Lerer, Boethius and Dialogue: Literary Method in The Consolation of Philosophy, Princeton, NJ: Princeton University Press, 1985.

14 Pseudo-Democritus, Scritti alchemici, con il commentario di Sinesio. Edizione critica del testo greco, traduzione e commento (ed. and trans. Matteo Martelli), Paris and Milan: SEHA and Archè, 2011; Matteo Martelli (ed. and trans.), The Four Books of Pseudo-Democritus (Sources of Alchemy and Chemistry, 1), Leeds: Maney Publishing, 2013; Vincenzo Carlotta (ed. and trans.), The Teachings of Cleopatra (Sources of Alchemy and Chemistry, 2), London: Taylor and Francis, forthcoming.

15 Translation by Martelli, op. cit. (14). 
Here technical instruction is filtered through the exposition of 'philosophical' speech: a distinctive feature of alchemical literature that was duly adopted by Arabic and Latin commentators. To transform nature, the argument goes, it is first necessary to understand nature; an enquiry into causes that is the remit not of the artisan, but of the philosopher. The result is a body of instructional literature that claims to offer practical mastery, but only within the framework of learned discourse: an outlook that at times assumes an explicitly anti-artisanal flavour. ${ }^{16}$

This tone is particularly noticeable in the context of fourteenth-century philosophical treatises written after alchemy had been effectively excluded from the medieval university curriculum. These include a range of influential but largely pseudonymous writings attributed to scholarly authorities like the Montpellier physician Arnald of Villanova (c.1240-1311), Majorcan philosopher Ramon Llull (1232-1316), and English monk John Dastin (c.1295-before 1386). ${ }^{17}$ Since the ability to read texts on multiple levels, including allegorically, is the remit of the scholar, these authorities argue that an unlearned practitioner cannot prosper in the science of alchemy.

This point is made explicit in the De secretis naturae, a fourteenth-century treatise pseudonymously attributed to Arnald of Villanova. The text consists of a dialogue in which the master assures his disciple that "no one should therefore come to this art unless he has first learned logic, and afterwards philosophy, and knows the causes and natures of things'. ${ }^{18}$ While this emphasis on causes helps to situate alchemy within Aristotelian natural philosophy, it also distinguishes the context of alchemical learning from artisanal apprenticeship. Reading alchemically means reading philosophically, which in turn means approaching texts on multiple levels, rather than accepting terms at face value, as in a recipe. Accordingly, the value of an alchemical treatise at least partly resides in the author's ability to expound the philosophers' language.

In the preface to De secretis naturae, the master signals this method by announcing some of the terms that he intends to explicate:

In the first [chapter], I declare what the Stone is. Secondly, I say why the Stone is called the 'natural stone'. In the third, I say why it is called our 'animal stone', or blood. In the fourth, why it is called 'herbal'. In the fifth, I declare its preparation, with its various causes and sure understanding. In the sixth, I describe every multiplication of the weight of our stone, briefly and selectively, in this manner: I speak thus in order to mock fools, and teach wise men [Dicam ut fatuos derideam, sapientes doceam.$^{19}$

16 On the status of alchemy as scientia, and its place in medieval art-nature debates, see William R. Newman, 'Technology and alchemical debate in the late Middle Ages', Isis (1989) 80, pp. 423-45; Newman, Promethean Ambitions: Alchemy and the Quest to Perfect Nature, Chicago: The University of Chicago Press, 2004.

17 On the pseudo-Arnaldian corpus see Antoine Calvet, Les oeuvres alchimiques attribuées à Arnaud de Villeneuve: Grand oeuvre, médecine et prophétie au Moyen-Âge, Paris and Milan: SEHA and Archè, 2011. On Pseudo-Lull see Michela Pereira, The Alchemical Corpus Attributed to Raymond Lull, London: Warburg Institute, 1989; Pereira, L'oro dei filosofi: Saggio sulle idee di un alchimista del Trecento, Spoleto: Centro Italiano di Studi sull'Alto Medioevo, 1992. On Dastin, the only one of the named authors who seems actually to have written on alchemy, see Lynn Thorndike, A History of Magic and Experimental Science, 8 vols., New York: University of Columbia Press, 1923-58, vol. 3, pp. 85-102; W.R. Theisen, 'John Dastin's letter on the philosopher's stone', Ambix (1986) 33, pp. 7887; José Rodríguez-Guerrero, 'Un repaso a la alquimia del Midi Francés en al siglo XIV (parte I)', Azogue: Revista electrónica dedicada al estudio histórico crítico de la alquimia (2010-13) 7, pp. 75-141, 92-101.

18 Pseudo-Arnald of Villanova, De secretis naturae, in Calvet, op. cit. (17), pp. 490-523, 490: 'Nullus ergo ad hanc scientiam veniat nisi primo audiverit logicam, postea philosophiam, et sciat causas et naturas rerum'. On the dating of the treatise and its relation to other works in the Arnaldian corpus see Calvet, op. cit. (17), pp. 107-33.

19 Pseudo-Arnald, op. cit. (18), p. 490: 'In primo dicam quid est lapis. Secundo dicam quare dictus est lapis naturalis. In tertio dicam quare vocatus est lapis noster animalis, sive sanguis. In quarto quare vocatus est 
As Pseudo-Arnald's alliterative warning makes clear, the aim of the text is not to provide literal, step-by-step instruction of the kind furnished by traditional craft literature. Rather, obscure speech is deliberately employed to protect the knowledge of alchemy from 'fools'. As the master explains, if a man were known to have the secret he would be pursued for it, and in the hands of the unworthy it might bring ruin to the world. Practitioners who abused such knowledge would then be answerable for their actions before God. For all these reasons, the master prays that God will grant him the ability to reveal the secret to the wise, while concealing it from the ignorant. ${ }^{20}$

This pious rhetoric obscures a more pragmatic agenda. Pseudo-Arnald here uses the magisterial framing to promote his own approach to alchemy, namely a practical and theoretical commitment to using metallic rather than organic ingredients in the work of chrysopoiea (gold-making). Much of the pseudo-Arnaldian corpus belongs to a 'mercurialist' tradition that viewed metallic bodies, particularly quicksilver, as the most appropriate basis for operations intended to produce gold and silver. ${ }^{21}$ Since this contradicted authorities who advocated the use of blood, eggs and other organic ingredients, one strategy was to forcibly reinterpret these writings by reading such substances as cover names, or Decknamen. Accordingly, the magister warns that, while the philosophers state that the stone is made from herbs, eggs or blood, such terms must be understood not literally but philosophically. Fools who read only 'according to the letter' have wasted their labour on eggs, blood, salts and so forth, 'because they did not well understand the words of the philosophers, speaking obscurely.'22 For instance, although the philosophers used 'blood' in a purely metaphorical sense to refer to the stone's red colour, the term is misunderstood by fools, who 'have worked on blood and found nothing,. ${ }^{23}$

These instructions were later taken seriously as advice for the correct interpretation of alchemical books. Through such expository techniques, readers who had never studied natural philosophy in a formal educational setting could still learn to read alchemically from medieval texts. Books like De secretis naturae, which circulated both under Arnald's name and in an anonymous form as the Dialogus inter magistrum et discipulum, continued to serve as important sources of information on alchemical philosophy throughout the fifteenth and sixteenth centuries, while also providing exemplars for new treatises. In the process, they helped to enshrine mercurialist precepts - such as a disdain for salts and organic ingredients in favour of the metallic trinity of gold, silver and mercury in alchemical lore.

In England, for instance, the second half of the fifteenth century witnessed a blossoming of didactic tracts on alchemy written both in Latin and in Middle English, which often follow the pseudo-Arnaldian model. ${ }^{24}$ The dialogue format, which offers advice on

herbalis. In quinto dicam preparationem eius cum causis varis et certis intelligenti. In sexto dicam omnem multiplicationem ponderis nostri lapidis breviter et sumatim taliter. Enim dicam ut fatuos derideam, sapientes doceam'.

20 Pseudo-Arnald, op. cit. (18), p. 492: 'Primo quia eam omnes scivissent, secundo quia mundus destructus fuisset, tercio quia essent coram Deo de factis eorum reddituri racionem. Ideo Deo supplico ut det mihi intellectum et viam ut celem stultis et fatuis et declaram sapientibus'.

21 This approach is dubbed 'mercury alone' by Thorndike, op. cit. (17), vol. 3, pp. 89-90, and as 'mercurialist' in Lawrence M. Principe, The Aspiring Adept: Robert Boyle and His Alchemical Quest, Princeton, NJ: Princeton University Press, 1998, pp. 153-5. See also William R. Newman (ed.), The Summa Perfectionis of Pseudo-Geber: A Critical Edition, Translation and Study, Leiden: Brill, 1991, pp. 204-8.

22 Pseudo-Arnald, op. cit. (18), p. 492: 'Fatui autem intelligentes litteram operati sunt de ovis, de sanguine, de capillis, de rebis, de aluminibus, de salibus, et nihil invenerunt quia non bene intellexerunt dicta philosophorum obscure loquentium'.

23 Pseudo-Arnald, op. cit. (18), p. 502. 'Operati sunt in sanguinem et nihil invenerunt'.

24 On alchemical writings in Middle English see Anke Timmermann, Verse and Transmutation: A Corpus of Middle English Alchemical Poetry, Leiden: Brill, 2013; Peter J. Grund, 'Misticall Wordes and Names Infinite': An Edition and Study 
interpretive issues while reinforcing the authority and prestige of past philosophers, was retained in several versions. Thus one Middle English dialogue opens with a student's request for clarification of past errors in order to uphold the credibility of the science:

I pray you, master, that I mighte be so bolde to aske certayne questyons, to have full knowledge of the great errors, that I have had offte tymes in thys science, that hereaffter by you I mighte have perffecte knowledge, and then I woulde gyve you credence to your discypline. ${ }^{25}$

The novice goes on to press his teacher regarding various points of interpretation, and receives familiar answers, starting with the need to eschew animal and vegetable ingredients in favour of mineral ones. The master even cites Pseudo-Arnald's advice on Decknamen: 'Therffore [th]e philosophers toke no heede to [th]e names but to [th]e properties of [th]e names. ffor, by one thynge they vnderstoode another' ${ }^{26}$ Similar warnings are offered in another Middle English dialogue, also modelled on De secretis naturae, titled 'certeyn necessary questions of a disciple and of the solucions therto made by his master touchyng the seid werke and materialles' ${ }^{27}$ Here, through the catechetical form of a set of quaestiones, the disciple attempts to establish the true nature of the philosophers' mercury, and learns the dangers of alchemical speech. The master offers a familiar warning: since 'The philosophres in [t]her termes spekyn analogies', their followers must 'be ware of analogia for in the most derkist maner all this matter is hidde'. ${ }^{28}$ Mercury, for instance, may not always represent common quicksilver, but a powerful solvent drawn out of the bodies of metals.

By opening the gates to multiple levels of interpretation, these fictive masters offered exegetical opportunities to their readers. This is more than straightforward translation, whereby one Deckname is consistently interpreted in a given way. Rather, this mode of reading all but guarantees lexical slippage over time, as earlier texts are continually reread in light of new sources of evidence, including the results of experimentation. 'Mercury' could be interpreted in many different ways - and frequently was. ${ }^{29}$

The conventions of alchemical instruction literature also make it very easy for writers to disguise the fact that they have not yet (we presume) achieved the stone. But why write a 'how-to' treatise at all, if one has yet to personally discover the 'how'? When we turn to the context of sixteenth-century England, it becomes clear that these writings played an important role beyond directing practical operations, although they undoubtedly served that end as well. Among communities of readers and practitioners, instructional treatises helped to support the prestige of alchemy as a branch of natural philosophy, and that of individual alchemists as true 'philosophers' - a persona viewed as particularly useful in

of Humfrey Lock's Treatise on Alchemy, Tempe: Arizona Center for Medieval and Renaissance Studies, 2011; Linda Ehrsam Voigts, 'Multitudes of Middle English medical manuscripts, or the Englishing of science and medicine', in Margaret R. Schleissner (ed.), Manuscript Sources of Medieval Medicine: A Book of Essays, New York: Garland, 1995, pp. 183-95; Peter J. Grund, 'The golden formulas: genre conventions of alchemical recipes in the Middle English period', Neuphilologische Mitteilungen (2003) 4, pp. 455-75. On vernacular translation more generally see Michela Pereira, 'Alchemy and the use of vernacular languages in the late Middle Ages', Speculum (1999) 74, pp. 336-56.

25 British Library, MS Sloane 3580B, fol. 131r. When reproducing text from manuscript, I retain original spelling and capitalization, using italics to denote the expansion of contractions or abbreviations. Information necessary to convey the sense of a word or passage (including the translation of symbols) is included within square brackets.

26 Sloane 3580B, fol. $134 \mathrm{r}$.

27 Bodleian Library, MS Ashmole 759, fol. 49r.

28 Ashmole 759, fol. 49r.

29 I dub this approach 'practical exegesis' in Rampling, op. cit. (4). 
the context of patronage. ${ }^{30}$ We can trace exactly this process in the case of one alchemist at the court of Henry VIII: Giles Du Wes. Not only does Du Wes's own philosophical dialogue survive, but also several of the manuscripts that he read as source material, as well as evidence for his correspondence with at least one other contemporary practitioner. The case therefore offers an unusual glimpse of a Henrician practitioner in the round, as a reader, a writer and - eventually - an authority in his own right.

\section{Writing alchemically}

Learning to read alchemically was not unlike learning a foreign language - one populated by 'false friends' that did not always produce the expected meaning. As the priest and tutor John Palsgrave (c.1485-1554) explained in the introduction to his 1530 French grammar, the phrasing of French differed from that used in English: 'thoughe we shulde gyve worde for worde, yet the sens shulde moche differ betwene our tong and theyrs'. ${ }^{31}$ Alchemical readers faced similar problems when interpreting difficult terms, but the language of alchemy could not be learned through casual conversation, nor gleaned from a single primer. In the absence of a definitive dictionary, readers turned to philosophical treatises for advice on translating the words of their authorities, including multivalent terms like 'mercury'. In practice, these books were often just as obscure as the authorities they claimed to decipher - evidence, perhaps, that their writers had correctly learned the rhetorical lessons of past masters, and successfully put them to work in their own compositions.

In England, one important guide to alchemical reading was coincidentally written by the author of one of the earliest French textbooks, Giles Du Wes. Also known by his Latinized name of Ægidus de Vadis, Giles began his career in England as a musician at King Henry VII's court. After teaching French and lute playing to the king's children (including the future Henry VIII), he was put in charge of the royal library at Richmond Palace in $1506 .{ }^{32}$ It was there that he composed his Dialogus inter naturam et filium philosophiae (Dialogue between Nature and a Son of Philosophy) in 1521, dedicating the work to an unnamed friend, most likely his fellow practitioner Sir Robert Greene of Welby (c.1467-after 1544). ${ }^{33}$

As the title suggests, this Latin treatise is presented as a dialogue between a would-be philosopher and the personification of Nature, who generously undertakes to tutor her disciple in the art of alchemy. ${ }^{34}$ Its form owes much to Du Wes's familiarity with medieval alchemical texts like the 'Dialogue between a Master and a Disciple', the anonymized version of the pseudo-Arnaldian De secretis naturae, which he owned (and personally repaired)

30 On the crafting of such personae in relation to patronage see particularly Tara Nummedal, Alchemy and Authority in the Holy Roman Empire, Chicago: The University of Chicago Press, 2007.

31 John Palsgrave, L'esclarcissement de la langue francoyse, London, 1530; reprinted as L'éclaircissement de la langue française ... la grammaire de Gilles Du Guez (ed. F. Génin), Paris, 1852, p. xv.

32 I discuss Du Wes's collection and composition of alchemica in detail in Rampling, op. cit. (3), Chapter 4. See also Gordon Kipling, 'Duwes [Dewes], Giles [pseud. Aegidius de Vadis] (d. 1535)', Oxford Dictionary of National Biography, accessed July 2020.

33 Aegidius de Vadis, Dialogus inter Naturam et Filium Philosophiae, Accedunt Abditarum rerum Chemicarum Tractatus Varii scitu dignissimi ut versa pagina indicabit (ed. Bernard G. Penot), Frankfurt, 1595; reprinted in Lazarus Zetzner (comp.), Theatrum chemicum, praecipuos selectorum auctorum tractatus de chemiae et lapidis philosophici antiquitate, veritate, iure, prcestantia et operationibus ..., vol. 2, Strassburg, 1622, pp. 89-123. I argue for Du Wes's relationship with Greene in Rampling, op. cit. (3), Chapter 4.

34 Nature was a familiar protagonist in medieval dialogues, most famously in the De planctu naturae of Alain of Lille (d. 1202). In alchemical contexts see Michela Pereira, 'Natura naturam vincit', in José Luis Fuertes Herreros and Ángel Poncela González (eds.), De natura: La naturaleza en la Edad Media, 2 vols., Oporto: Húmus, 2015, vol. 1, pp. 101-20; Newman, op. cit. (16), Promethean Ambitions, pp. 77-82. 
in a fifteenth-century copy. ${ }^{35}$ As a teacher, however, Du Wes was also familiar with the use of dialogues in more conventional didactic settings. During the late 1520 s he rounded out his pedagogical credentials with An introductorie for to lerne to rede, to pronounce and to speke French trewly, a grammar based on his experience of teaching Henry VIII's own daughter, Mary. ${ }^{36}$ The dialogic format is essential to the Introductorie, which includes a series of exercises framed as conversations between Giles and his royal pupil. In terms of content, these are designed to showcase a range of vocabulary while doubling as an etiquette manual for interacting with court dignitaries and their messengers. However, they also hint at $\mathrm{Du}$ Wes's philosophical interests. In one dialogue, Du Wes responds to Mary's questions on the nature of the soul with a natural-philosophical digression on the functions of human digestion: material that, as we shall see, he also used as an analogy for chemical operations in the alchemical Dialogus. Such interjections served to demonstrate Giles's learning and courtliness in ways that masked his humble minstrel origins. But the primary purpose of the exercise was not, of course, to teach readers philosophy - it was to allow them to practice their French, perhaps with the added frisson of learning page-by-page with the king's daughter.

Du Wes's French grammar thus offers some intriguing parallels with his Dialogus, which as a 'manual' of alchemy leaves much to be desired in terms of practical oversight of chemical operations. Rather, the text emphasizes the exegetical techniques necessary for readers to present themselves as educated specialists. The tone is set in the preface, which relates how the protagonist, after years of fruitless labour searching after the secrets of nature, has reached the point of abandoning alchemy altogether. He is hopelessly entangled in the enigmas and allegories of his source texts, 'for all philosophers are sententious to such a degree, they are not content with a small level of difficulty but wrap up [the answer] in so many riddles that I don't think anyone could arrive at the desired outcome by themselves'. ${ }^{37}$ The alchemist's problems therefore arise not from a lack of technical skill (since he admits to having attempted a variety of practices already) so much as from his inability to understand his written sources, which are essential if he is to conclude the work successfully. As in the Introductorie, mastery of language is the ultimate goal of the book: a mastery that, once used to 'translate' the words of the authorities into clear speech, will raise even humble men to the rank of philosopher.

The difficulties of reading alchemically are stated particularly clearly in relation to the central problematic of the Dialogus: that of the philosophical proportion. The problem is introduced when the disciple asks Nature to reveal the correct proportion of ingredients used in making the stone. In a straightforward technical manual, we might expect straightforward answers. But the purpose of the dialogue is not to provide recipes or lists of quantities, and Nature does not interpret it as such. Rather, she takes the question as her cue to explain the methods by which the philosophers disguised their true meaning. One way is to discuss chemical operations by analogy. Nature demonstrates this skill herself, responding to the question of proportion by developing an analogy with human appetite:

35 'Dialogus inter magisterium et discipulum', British Library, MS Harley 3528, fol. 93v. Du Wes transcribed the beginning of the text in his own hand, to make up for the loss of half of the first folio, which has been torn out.

36 Giles Du Wes, 'An introductorie for to lerne to rede, to pronounce and to speke French trewly', in Palsgrave (ed. Génin), op. cit. (31). On the teaching of French in early modern England see Kathleen Lambley, The Teaching and Cultivation of the French Language in England during Tudor and Stuart Times, Manchester: Manchester University Press, 1920.

37 De Vadis, op. cit. (33), p. 326: 'nam Philosophi omnes sunt adeo sententiosi, una tamen difficultare minime contenti, tantis ambagibus tam involvunt, ut per eas neminem ad optatum finem pervenire posse arbitret'. 
When you are hungry and see food you do not know how much of it is enough for you, but in eating you immediately perceive how much you need by the virtue of your stomach. Therefore do likewise in your magistery. ${ }^{38}$

At a superficial level, this looks like good advice. Different people (or even the same person under different conditions) will be satiated by different amounts of food: we discover the extent of our appetite only by satisfying it. Likewise, the alchemical adept must be able to adapt to the situation and ingredients at hand, rather than deciding in advance on a 'one-size-fits-all' procedure. This solution has important practical connotations, since the quality and quantity of the alchemist's matter will determine the amount of 'feeding' it requires: a problem often encountered in practicae such as George Ripley's Philorcium (a work which Du Wes partly transcribed), which warn against over-saturating one's ingredients with liquid. ${ }^{39}$

Yet Nature's advice to learn by doing is too simplistic for her disciple, since it ignores the underlying causes of chemical change. The amount that a given stomach can digest depends on its particular complexion: thus a hot and strong stomach will digest far more than one that is cold and weak. Since given ingredients have specific complexions, success must depend on combining them in the right proportion. The disciple concludes that Nature is treating him like a rustic rather than instructing him in the approved philosophical manner - that is, with reference to causes. He suspects that the work does rely on a 'determinate measure', and begs his preceptress to disclose it. ${ }^{40}$

Such bluntness gets short shrift from Nature. True philosophers do not communicate their knowledge so baldly - at least, not in writing:

For these things should be neither openly declared nor made clear, except to those who fear God, and then only by conversing with one another [per colloquiam]: because in writings they can be seen by the unworthy as well as the worthy. Wherefore some say this science to be part of Cabala, which reception [receptio] is explained through speech. For the philosophers, treating of these things, wrap them in such enigmas, allegorical writings, glyphs, and riddles, that Pythagoras teaches as much with his silence as they do in their writings. ${ }^{41}$

For Du Wes, who had studied the writings of humanist scholars like Giovanni Pico della Mirandola (1463-1494) and Johannes Reuchlin (1455-1522), their Christianized version of Cabala offered an attractive analogy with alchemy. ${ }^{42}$ Both were learned, esoteric

38 De Vadis, op. cit. (33), p. 330: ‘[C]um esuris \& vides cibaria, ignorae quantum ex eis tibi sufficiat, comedendo illico sentis virtute tui stomachi, quantum tibi convenit, fac ergo similiter in tuo magisterio'.

39 Trinity College Library, MS 0.8.25, fols. 163v-165r. The Philorcium extracts copied by Du Wes are those that deal particularly with the errors of false practitioners, and the cover names employed by philosophers to conceal their meaning.

40 De Vadis, op. cit. (33), p. 331: 'Certus enim sum his sicut in caeteris pondus certum esse determinatum; tu vero me hic instruis, non per causam quemadmodum Philosophi scire oportere dicunt: sed potius sicut rustici idiotae hujusmodi probare solent; eo quod calidus stomachus, \& fortis plus potest in digerendo quam frigidus \& debilis in productione alicujus speciei de potentis ad actum; opinor tibi certam mensuram esse observandam, imo pondus atque numerum determinatum, \& quod hoc fit causa totius effectus'.

41 De Vadis, op. cit. (33), p. 331: '[I]sta tamen non sunt palam dicenda neque manifesta, nisi Deum timentibus, \& hoc per colloquia, eo quod scripta tam ab indignis, quam dignis videri possunt, quare aliqui dixerunt, istam scientiam esse partem cabalae, quae receptio interpretatur per colloquiam scilicet. Nam Philosophi de ea tractantes tantis aenigmatibus, tropicis scriptis, gryphis, atque problematibus involvunt, quod tantum docet Pythagoras suo silentio, quantum ipsi scripturis suis'.

42 On Du Wes's interest in Cabala see Rampling, op. cit. (3), pp. 151-3; François Secret, Les Kabbalistes chrétiens de la Renaissance, Paris: Dunod, 1964, p. 229; Didier Kahn, Alchimie et Paracelsime à la fin de la Renaissance (1567-1625), 
traditions whose true sense was not conveyed in plain writing, but rather through oral communication and close textual exegesis. Like Cabalists, novice alchemists should therefore seek out a master willing to reveal the secret to them directly. Failing that, practical knowledge might still be set down in writing if appropriately disguised. While these texts made little sense on their own, a skilful reader could extract their meaning by comparing multiple authorities.

Thus, in a long passage often omitted in manuscript copies, Du Wes piles up aphorisms on the philosophical proportion culled from his own study of medieval sources. Although these often seem to contradict one another, Nature glibly assures her follower that their underlying coherence can be revealed by further study and reflection; or, failing that, with prayer:

Son, to that purpose I might have brought up more of their sayings, but in my judgement these seem able to satisfy your doubts, if you understand them: for although they seem to differ from one another in meaning, they nonetheless agree with one another in sense and intention ... Truly, if you cannot understand on the first reading those things which I related to you, repeat the reading, and ask the Creator that He deign to illuminate your understanding. And so you shall finally discover that which you seek. ${ }^{43}$

The entire passage on proportion, from the stomach analogy to the long list of contradictory authorities, may seem unhelpful for those in need of step-by-step technical instruction. At no point does Nature actually explain what the correct proportion is. Having come this far, the disciple needs either to develop his own understanding to the point where he perceives the truth, or to find a master willing to convey the necessary information orally. Nature's advice does, however, offer important clues on how to approach alchemical texts, to both readers and prospective authors. Her series of examples demonstrates how analogies can be constructed to disguise alchemical problems, and shows how similar riddles can be solved when encountered elsewhere. Above all, Du Wes's compositional ambiguities mask the fact that he had yet to determine the correct proportion himself. As Nature responds to the disciple's questions, she voices the answers that Giles has arrived at through his own painstaking study and annotation of philosophical treatises, particularly pseudo-Lullian writings.

It is possible to partially reconstruct this process, because we actually have access to some of Giles's own manuscripts, which allow us to catch the librarian himself in the act of learning to read like a philosopher. In or around 1506, Giles annotated his copy of the Liber de secretis naturae, seu de quinta essentia (The Book of the Secrets of Nature, or, Concerning the Quintessence - not to be confused with the Arnaldian De secretis naturae), one of the core works of the pseudo-Lullian alchemical corpus. ${ }^{44}$ Here, the

Geneva: Librairie Droz, 2009, p. 65. On the early modern interest in linking alchemy to Cabala see Peter J. Forshaw, 'Cabala Chymica or Chemia Cabalistica: early modern alchemists and Cabala', Ambix (2013) 60, pp. 361-89.

43 De Vadis, op. cit. (33), p. 333: 'Fili, ego possem adducere adhuc plura eorum dicta ad istud propositum, sed meo judicio ista videntur dubiis tuis satisfacere posse: si illa intelligis, quia quamvis diversificantur invicem, in sententiis concordant tamen omnes, in sensu \& intentione ... Tu vero si prima lectione quae tibi retuli intelligere nequiveris, reitera lectionem: \& roga Creatorem ut tuum intellectum illuminare dignetur. Et sic finaliter quod quaeris invenies'.

44 On the structure and influence of this text, which is heavily based on an earlier work of medicinal alchemy, the De consideratione quintae essentiae (1351-2) of John of Rupescissa, see Pereira, The Alchemical Corpus Attributed to Raymond Lull, op. cit. (17), pp. 11-20; Michela Pereira, 'Filosofia naturale lulliana e alchimia: Con l'inedito epilogo del Liber de secretis naturae seu de quinta essentia', Rivista di storia della filosofia (1986) 41, pp. 747-80; Pereira, 
late fourteenth-century writer explains that the same alchemical 'water' can be congealed into either elixir or precious stones, 'according as the matter is proportioned [to] either' ${ }^{45}$ Giles underlined this passage, noting in the margin that these proportions were hard and difficult to determine, since none of the philosophers had fully explained them. ${ }^{46}$ Hints of his frustration linger in the Dialogus, written fifteen years later, where Nature and the disciple debate exactly this problem - although Nature's unresponsiveness suggests either that he failed to find a definitive answer, or that he preferred not to share his solution. For later readers, however, such vagueness over the problem of proportion could be readily interpreted as philosophical discretion rather than amateurish prevarication.

Du Wes knew that his books would be studied by others. Although the evidence for collaboration between English alchemists in the first half of the sixteenth century is generally much sparser than for later periods, Du Wes's manuscripts show that he did not study alchemy in isolation, but rather collected and composed texts with a view to instructing and impressing his peers. Indeed, he probably had a specific reader in mind: his fellow bibliophile (and likely social superior), Sir Robert Greene of Welby. ${ }^{47}$

Du Wes plied his colleague with both physical books and new, alchemical compositions. In 1532, he presented Greene with an alchemical manuscript, carefully copied and illustrated in his own hand. The book was composed of late medieval works as well as more recent writings, such as Augurello's Neo-Latin poem Chrysopoeia, all annotated by $\mathrm{Du}$ Wes. ${ }^{48}$ Greene acquired several more of Du Wes's books, including his annotated copy of the pseudo-Lullian Liber de secretis naturae, possibly after his friend's death in 1535. A note addressed to 'Robert' in another of Du Wes's manuscripts, and a reference to 'Sir Robert' accompanying an early translation of the Dialogus, suggest that Greene may even have been the anonymous dedicatee whom Du Wes praises in the preface to his work. ${ }^{49}$ Their relative social status is suggested by the fact that it is Du Wes, rather than Greene, who seems to have initiated correspondence in the form of gifts and dedications, while Greene later erased Du Wes's name from his former manuscripts - overlaying the librarian's signature with his own. ${ }^{50}$

Yet the content of Du Wes's writings suggests that, despite his lack of birth or conventional scholarly education, he nonetheless envisaged himself as Greene's equal in matters of alchemical philosophy. Such previously unnoticed associations between two prominent Henrician alchemists draw attention to a context of knowledge making in which

\footnotetext{
'Sulla tradizione testuale del Liber de secretis naturae seu de quinta essentia attribuito a Raimondo Lullo: Le due redazioni della Tertia distinctio', Archives internationales des sciences (1986) 36, pp. 1-16. On its English reception see Rampling, op. cit. (3).

45 Pseudo-Ramon Llull, Liber de secretis naturae, seu de quinta essentia, in Yale University, Beinecke Rare Book \& Manuscript Library, MS Mellon 12, fol. 222v: 'Et aqu[a]e aere[a]e habent potestatem indurari et coagulari, tam in elixir quasi in lapides preciosos secundum quod proporcionatur materia uel ad elixir uel ad lapides preciosos iam dictos'. On Du Wes's previously unrecognized connection with this manuscript, see Rampling, op. cit. (3), Chapter 4.

46 Marginal note by Giles Du Wes, Mellon 12, fol. 222v: 'quia durum \& difficile cum nemo philosophorum sit qui de istis proporcionibus tractet'.

47 On Greene see Andrew G. Watson, 'Robert Green of Welby, alchemist and count palatine, c.1467-c.1540', Notes and Queries (Sept. 1985), pp. 312-13; Jennifer M. Rampling, 'English alchemy before Newton: an experimental history', Circumscribere (2016) 18, pp. 1-11; Rampling, op. cit. (3), Chapter 4.

48 Cambridge, Trinity College Library MS 0.8.24. On the book's contents, and the evidence for its presentation to Greene, see Rampling, op. cit. (3), Chapter 4. On Du Wes's annotations to this manuscript see also Zweder von Martels, 'Augurello's “Chrysopoeia” (1515): a turning point in the literary tradition of alchemical texts', Early Science and Medicine (2000) 5, pp. 178-95.

49 Cambridge, Trinity College Library MS 0.8.25, fol. 3v: 'Experto crede Roberto'; Boston, Massachusetts Historical Society, Winthrop 20c, fol. $89 \mathrm{v}$ : 'Hec erant domine mi roberte que tue dominacioni ob tuarum virtutum amorem offere nitebar' (at the conclusion of an English translation of the Dialogus).

50 See, for instance, Mellon 12, fol. 312v.
} 
alchemical manuscripts functioned not only as sources of practical instruction, but also as evidence for mastery in the techniques of alchemical exegesis - and hence as a form of both social and intellectual currency, suitable for scribal circulation among like-minded associates and even prospective patrons.

These advantages also benefited writers in the long term. Within a few decades $\mathrm{Du}$ Wes's reputation had eclipsed that of Greene, who abandoned alchemical practice in 1538 and bequeathed no substantial philosophical treatise to posterity. ${ }^{51}$ In his own philosophical dialogue, Du Wes's readings of medieval manuscripts (some later owned by Greene) accreted authority as he translated them directly into Nature's pronouncements. These lessons were noted by later readers, who studied and transcribed the Dialogus long after Giles's death, both in its original Latin and in an English translation, the 'Dialogue between Nature and a Disciple'. ${ }^{52}$ For instance, when the Elizabethan alchemist Thomas Potter transcribed the English version in 1580, he drew attention to Nature's warnings, noting that the philosophers' true proportion 'may not be put in writinge', for it is '[th]e kay of all our secretes'. ${ }^{53}$ In the margins of alchemical texts, conversations unfolded not between Nature and her baffled disciple, but between writers, their books and their future readers.

\section{Reading for practice}

As the sixteenth century progressed, the number of recorded suits from alchemical practitioners rose, partly in response to the known interest of influential royal administrators such as William Cecil, Lord Burghley (1520-98) and Sir Thomas Smith (1513-77) in both the chrysopoetic and medical applications of alchemy. ${ }^{54}$ Yet winning the support of powerful patrons like Cecil and his mistress, Elizabeth I, posed problems for practitioners who lacked courtly connections or a university education. For such petitioners, the philosophical framing offered by medieval authorities provided one model for achieving respectability. By the 1560s, large numbers of Latin treatises had been translated into English, providing fuel for a generation of English merchants and tradesmen who incorporated their lessons into their own practice - and also their own patronage suits. ${ }^{55}$

One such reader was the merchant Humfrey Lock, whose suit to Cecil has recently been edited by Peter Grund. As a gift for his patron, Lock composed a lengthy treatise consisting of excerpts from late medieval philosophical treatises, which include both Middle English compositions and 'Englished' versions of Latin works. In his dedication to Cecil, Lock lingers over the challenges presented by philosophical speech. For instance, he

51 He recounts his troubles in the English 'Work of Sir Robert Greene', discussed in Rampling, op. cit. (3), pp. 154-7, 167-8.

52 Although the English translation of the Dialogus was never printed, scribal copies are preserved in Bodleian Library, MSS Ashmole 1487 and 1490; British Library, MSS Sloane 3580B and 3762; and MS Winthrop 20c, op. cit. (49).

53 Sloane 3580B, fol. $198 \mathrm{r}-198 \mathrm{v}$.

54 On Cecil's and Smith's well-documented patronage of alchemical projects see especially James Stuart Campbell, 'The alchemical patronage of Sir William Cecil, Lord Burghley', unpublished MA thesis, Victoria University of Wellington, 2009; Deborah E. Harkness, The Jewel House: Elizabethan London and the Scientific Revolution, New Haven, CT: Yale University Press, 2007; Glyn Parry, The Arch-conjuror of England: John Dee, New Haven, CT: Yale University Press, 2012. On Smith's alchemical books see Richard Simpson, 'Sir Thomas Smith's stillhouse at Hill Hall: books, practice, antiquity and innovation', in Matthew Dimmock, Andrew Hadfield and Margaret Healy (eds.), The Intellectual Culture of the English Country House, 1500-1700, Manchester: Manchester University Press, 2015, pp. 101-16.

55 Some of these petitions are detailed in Campbell, op. cit. (54). On the 'Englishing' of Latin alchemica see Timmermann, op. cit. (24); Rampling, op. cit. (3). 
praises George Ripley's famous English poem the Compound of Alchemy (1471), for its usefulness in unpacking philosophical enigmas: 'wherby I haue lerned to knowe the croked way and the matter that the philosofers hid and coverid vnder the mantill of philosofie'. ${ }^{56}$

For modern readers of Ripley's difficult, technical, partly allegorical poem, the compliment may seem tendentious at best. But Lock was well aware of the value that knotty philosophical texts represented to an ingenious reader, who might use them as a platform for his exegetical skills. A note in one copy of his Treatise reveals that Lock was hoping to be recalled from a troublesome posting in Moscow, trading on Cecil's well-known interest in alchemy to facilitate his return. Despite not yet having made the stone, Lock trusted that the very obscurity of his writing would intrigue his well-read patron:

For when I compiled it, I ment to haue sent it into Ingland as a present \& mediator to help me home out of Russia, wherfore I made it the more darke that I might the sonner be sente for home for to doe it myselfe. ${ }^{57}$

Unfortunately Lock's own library does not survive in identifiable form to offer further insight into his reading practices. However, the arrangement of medieval material in the Treatise points to his access to a range of manuscripts which he studied closely for both practical and philosophical meaning. We are luckier in having access to annotated books owned by other alchemical suitors, ranging from university-educated humanists like Richard Eden (c.1520-76) and John Dee (1527-1609), to humbler figures, such as the clothworker Thomas Peter (fl. 1520s-1530s) and haberdasher Richard Walton (fl. 1560s). ${ }^{58}$

Walton is one of many English alchemists who lacked the scholarly credentials that authorities like Pseudo-Arnald demanded as the foundation for philosophical pursuits. The demands of his business also denied him time for study and contemplation, as he notes in his own treatise written for Elizabeth I, where he dwells wistfully on the opportunities available to ancient adepts who studied the liberal arts while financially supported by relatives and friends, that they might giue their Mindes wholly to their studdy, and to the practize of those things by which by their learning they had the speculation of ${ }^{59}$ He nonetheless works hard to convince the queen that true knowledge of alchemy depends not just on book learning, but also on the providence of God, which opens the science to lowly as well as wealthy men. ${ }^{60}$ Accordingly, the ability to read texts alchemically is evidence not just of scholarship, but also of elect status. ${ }^{61}$

56 Grund, 'Misticall Wordes and Names Infinite', op. cit. (24), p. 210 (11. 16-23). On Ripley's Compound see Jennifer M. Rampling, 'The catalogue of the Ripley Corpus: alchemical writings attributed to George Ripley (d. ca. 1490)', Ambix (2010) 57, pp. 125-201, 151-62. The text is edited in Elias Ashmole (ed.), Theatrum Chemicum Britannicum: Containing Severall Poeticall Pieces of Our Famous English Philosophers, Who Have Written the Hermetique Mysteries in Their Owne Ancient Language. Faithfully Collected into One Volume with Annotations Thereon, London, J. Grismond for N. Brooke: 1652, pp. 107-93.

57 Grund, 'Misticall Wordes and Names Infinite', op. cit. (24), 11.

58 On these readers and their manuscripts see Rampling, op. cit. (3), Chapter 6.

59 Richard Walton, Letter to Elizabeth I, British Library, MS Sloane 3654 , fols. $14 \mathrm{v}-17 \mathrm{r}, 14 \mathrm{v}$. I discuss this previously unidentified petition in Rampling, op. cit. (3), pp. 232-5, 240-2.

60 On Elizabethan attitudes to providence see Alexandra Walsham, Providence in Early Modern England, Oxford: Oxford University Press, 2001.

61 Walton, op. cit. (59), fol. 15v: 'it pleaseth god to bestow his great grace vpon pure and simple men'. On the impact of divine election on alchemical prowess see also R.M. Schuler, 'William Blomfild, Elizabethan alchemist', Ambix (1973) 20, pp. 75-87, 82-5. The astrologer and physician Simon Forman made strong claims for divine sanction and revelation in his own writings, as examined in Lauren Kassell, Medicine and Magic in Elizabethan London: Simon Forman: Astrologer, Alchemist, and Physician, Oxford: Clarendon Press, 2005, pp. 53-72 ('How to write like a magus'). 
Regardless of whether his exegetical prowess flowed from erudition or divine grace, Walton accepted mastery of Decknamen as an essential part of acquiring this philosophical craft. In his own annotations to Ripley's Compound, he observes that 'every syence hathe hys proper tearmes' - alchemy included. And he shows that he understands the lesson: one must learn the meaning of each and every one of these terms, 'or ellse you shallt be no philosophors but a broyler' ${ }^{62}$ In fact, Walton's note is itself a quotation from another alchemical poem, Thomas Norton's Ordinal of Alchemy (1477), which he had transcribed in October 1565:

I praye you laye men hollde me excusyd

thoughe syche tearmes with you be not usyd

I must use them for all authors affermes

how every syence hathe hys proper tearmes. ${ }^{63}$

Perhaps even more so than Du Wes's scholarly dialogue, alchemical poems like the Compound and Ordinal confound modern notions of 'how-to' literature. Yet their writers' reputations for successful practice, coupled with their sage advice on deciphering philosophical speech, ensured that their verses were routinely studied by readers concerned to extract practical information. ${ }^{64}$ For instance, Walton's notes to the Compound show that he was interested in Ripley's use of 'gold' and 'silver' as cover names for the true prime matter, a base metal: by 'thys ys not \mente/ gollde \& syllver vulger but phylosophicall'. ${ }^{65}$ Ripley's mystery ingredient contains gold and silver only in potentia, a point Walton underscores a few lines later: 'the sprytte ... of philosophers [is] neither golld nor syllver by natu[re] but by power. ${ }^{66}$ Later, in his own suit to Elizabeth I, Walton alluded to this metal using another common Deckname, the Sol of Philosophers, to signal his understanding that common gold was not required. ${ }^{67}$ From his reading, Walton identified this crucial prime matter as a mercurial water. Armed with this secret, 'Therefore, I learne to be begin'.

Walton's exegesis of Ripley's verbal substitutions opens a window into alchemists' attempts to read for practice. Alchemical reading techniques enabled practitioners to extract workable, chemical procedures from highly obscure source material, while also furnishing them with the skills to re-encode the fruits of their own experience in new, 'philosophical' forms. Lock's Treatise dedicated to Cecil and Walton's letter to Elizabeth I testify to the careful application of such compositional skills, learned from Ripley and other long-dead masters and honed in contexts unimagined by those late medieval authorities - ranging from the English merchant community in imperial Russia to a haberdasher's shop in Protestant London.

Seeking patronage was not the only pragmatic context wherein such techniques might be employed. Substituting the names of ingredients in correspondence, for instance, might protect the value of potentially lucrative secrets, particularly when communicating over distance. We find a striking example of such a technique on the parchment flyleaves of one late fifteenth-century alchemical manuscript, now MS Sloane 3747. Here, an Elizabethan reader has used the waste space to jot down a series of queries and

62 Bodleian Library, MS Ashmole 1479, fol. 8v; Walton's note on Ripley's chapter on 'Solution', stanza 21.

63 Walton's transcription of Norton's Ordinal, Ashmole 1479, fol. 277v; Norton, op. cit. (1), 55 (1l. 1727-30).

64 The reading of alchemical verses for practical information is discussed in detail in Timmermann, op. cit.

(24); see also Rampling, op. cit. (4).

65 Ashmole 1479, fol. 4v.

66 Ashmole 1479, fol. 5r.

67 Walton, op. cit. (59), fol. 16v: 'the solle of philosophers'. However, Walton followed Ripley by admitting that some gold would still have to be supplied as a necessary ingredient for a medicinal elixir (fol. 17r). 
instructions addressed to an unknown correspondent - questions which suggest the ways in which alchemical reading might shape actual discussions between practitioners.

In his notes, the annotator of Sloane 3747 shows that he has digested the lessons of the philosophical texts contained in the manuscript itself. Alongside other notes and queries, he advises his friend on the precautions to take when penning his response, in order to disguise the content of his recipes. 'In your lettres to me', he instructs, 'call golde Antymony'. Copper should be referred to as tutia; silver as arsenic; mercury as orpiment; lead as sal ammoniac; iron as flint; tin as talc; sulphur as 'Scales of Iron'; and 'Vitrioll of Copper' as minium. However, the 'mercury of mercury' may still pass under that name, 'for few knowe it'. Ingredients are not the only kind of information to be disguised: unfortunately for modern historians, the writer's correspondent is also advised to conceal his identity: 'Your owne name woulde not be set downe'. ${ }^{68}$

For the annotator, these verbal substitutions apparently had real-world application, since he asks his colleague to use them in their subsequent correspondence. Either his associate was already abroad at the time of writing or else his departure from England was imminent, since the annotator begs him to 'Enquier of Paull at hamburgh [whether a] booke dedicated to her Majestie was deliverde'. He also asks him to secure two copies of Thomas de Kempis's The Imitation of Christ while on the Continent, 'One for you, an other for me' - but preferably not the 1563 translation made by the French Protestant theologian Sebastian Castellio (1515-63), for 'the other is truer' ${ }^{69}$

This usage is particularly intriguing, because Sloane 3747 is one of the most important surviving repositories of fifteenth-century English alchemica, containing the earliest extant copies of numerous texts in verse and prose. ${ }^{70}$ These include several Middle English didactic writings, of which two are in dialogic form: the prose tract Certeyn necessary questions (discussed briefly above), and a poem sometimes attributed to Ripley, the Mistery of alchemists. ${ }^{71}$ The reader's notes suggest that he has absorbed the lessons of such sources - but also that he finds their contents insufficient on their own.

For this reason, the annotator's friend is expected to return from abroad with more than books alone. The mysterious Paul of Hamburg is apparently also an alchemist, whose knowledge the annotator hopes to tap regarding some of the technical aspects of chemical operations. For instance, when regulating the fire, what signs indicate when there is 'to muche heat or to litle' at the start of the work? As the writer well knew, such physical indications - the fruit of experience rather than scholarship - are all but impossible to convey in written form. He therefore asks his friend to pay attention to all aspects of Paul's practice during his visit: 'Be curious in preparations, Signes, Tyme, fiers or heates, vessells'. ${ }^{72}$

He also seeks knowledge from Paul that post-dates the kind of practical insight available from medieval sources. The majority of his queries are, in fact, less concerned with Paul's physical practice than with the interpretive problems of construing a new body of knowledge: the iatrochemical writings of the iconoclastic Swiss medical reformer

68 British Library, MS Sloane 3747, fol. 1v.

69 Sloane 3747, fol. 1v: The French Protestant theologian Sebastian Castellio (1515-63), also spelled Châtaillon, Castellión and Castello, translated the Imitation of Christ in 1563. See Hans R. Guggisberg, Sebastian Castellio, 15151563: Humanist and Defender of Religious Toleration in a Confessional Age (trans. Bruce Gordon), Burlington, VT: Ashgate, 2002.

70 The manuscript provides an important exemplar for several editions of Middle English alchemical verses in Timmermann, op. cit. (24).

71 Sloane 3747 , fols. $66-71,110-15$ respectively.

72 sloane 3747 , fol. 2 r. 
Theophrastus von Hohenheim, or Paracelsus (1493-1541). ${ }^{73}$ The annotator of Sloane 3747 has evidently read Paracelsus's Archidoxis, yet struggles to understand the meaning of his obscure terminology, perhaps understandably given Paracelsus's penchant for neologisms, and his unconventional use of quintessences and other chemical products of the kind described in medieval authorities, including sloane 3747 itself. ${ }^{74}$ He thus charges his correspondent to learn from Paul, "What his opynion of the Compounde Electrum of Paracelsus may be', and 'What Prima materia [it is] which Paracelsus noteth in his foure Arcana in his Archidoxis'. ${ }^{75}$ The slippery identity of mercury requires particular clarification. What substance does Paracelsus intend by 'mercury vitae'? And should antimony 'be subli[med] with [mercury] of th'elementes aforesaid, or with [mercury of] mercury, which you knowe'?

This list gives us one half of a real-life dialogue between two Elizabethan readers, offering tantalizing glimpses of an otherwise unwitnessed conversation between the writer's correspondent and the mysterious Paul of Hamburg. In this conversation, practical concerns are shaped by the experience of reading - the writer's final choice of ingredients depending on both exegesis of a text and the experience of a practising alchemist in a German workshop. Such cases reveal an economy of alchemical knowledge based on multiple sources of information, from bookish study to personal experimentation: activities that typically took place not in isolation, but within networks of readers, patrons and practitioners. Authoritative treatises played an important role within that economy, not just as introductions to the theory and practice of alchemy, but also as guides to, and expressions of, correct philosophical conduct. In the dialogue between text and practice, neither could be wholly teased apart from the other.

\section{Conclusion}

How did one learn alchemy in England in the sixteenth century? It seems that one answer is 'from medieval manuscripts'. With limited material available in print (let alone printed in the English language), alchemical practitioners looked back to pre-Reformation sources for advice. When these readers set their pen to the same page as their authorities, adding notes and glosses, or even composing complementary treatises of their own, they opened up dialogues on many levels. These were conversations with the dead, in which readers listened attentively to the words of past masters and sought to render down their obscure speech into replicable practices. In the process, their interpretations might alter the original sense of the text, as when ingredients like 'blood' or 'mercury' are redeployed as Decknamen for other substances. In such one-sided exchanges, the dead could not respond to the questions put to them, or correct any misunderstandings - but given the exigencies of alchemical language, they might not, in any case, have chosen to do so. In the margins of the page, readers' comments maintain the pretence of master-to-disciple communication even in cases where the master's intent has been eroded, picked apart by new conversations and concerns.

73 On the influence of Paracelsian chemical medicine in England see Charles Webster, 'Alchemical and Paracelsian medicine', in Webster (ed.), Health, Medicine and Mortality in the Sixteenth Century, Cambridge: Cambridge University Press, 1979, pp. 301-34. On Paracelsianism more generally see Kahn, op. cit. (42); Allen G. Debus, The Chemical Philosophy: Paracelsian Science and Medicine in the Sixteenth and Seventeenth Centuries, 2 vols., New York: Science History Publications, 1977.

74 Paracelsus, Archidoxa ... Zehen Bücher, Basel, 1570, translated as Paracelsus, his Archidoxis Comprised in Ten Books: Disclosing the Genuine Way of Making Quintessences, Arcanums, Magisteries, Elixirs, \&c ... (trans. J[ohn] $\mathrm{H}[$ ester]), London, 1660.

75 Sloane 3747 , fol. 2 r-v. 
The challenge for compilers of technical manuals is still, today, to successfully render down physical experience, much of which is tacit and honed by years of practice, into textual form. Yet both the danger and the appeal of alchemical reading lies in the fact that there are few limits on interpretation. If all the names of substances in a given authority can potentially be reread as Decknamen, how can consensus ever favour a single reading? The evidence of manuscript annotations suggests that different readers indeed came up with different solutions to the same textual problems; instances, perhaps, of how fluidity of interpretation also offered scope for chemical innovation, as terms like 'mercury' were repeatedly reread and re-evaluated - the chrysopoetic 'mercury' of Pseudo-Arnald of Villanova now set alongside the medical 'mercury' of Paracelsus. As the practical goalposts moved with new chemical innovations, alchemical readers retained the flexibility to stay perpetually ahead of the interpretive curve. Although alchemical handbooks offered no shortage of instruction, the philosophers' stone itself was always a work in progress.

Acknowledgements. I am grateful to the editors of this collection and the two anonymous readers for helpful comments, and to Richard Calis, Frederic Clark, Anthony Grafton and Madeline McMahon for many fruitful conversations on the nature of alchemical reading. I also thank the Warden and Fellows of All Souls College, Oxford, and the Council for Humanities at Princeton University for supporting the research and writing of this paper.

Cite this article: Rampling JM (2020). Reading alchemically: guides to 'philosophical' practice in early modern England. BJHS Themes 5, 57-74. https://doi.org/10.1017/bjt.2020.3 